This article was downloaded by: [Dalhousie University]

On: 10 September 2012, At: 04:45

Publisher: Taylor \& Francis

Informa Ltd Registered in England and Wales Registered Number: 1072954 Registered office: Mortimer House, 37-41 Mortimer Street, London W1T 3J H, UK

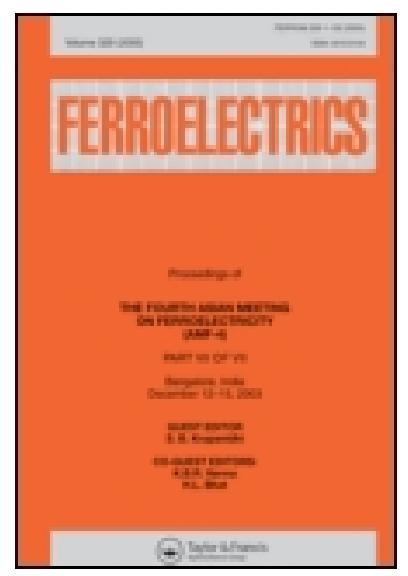

\title{
Ferroelectrics
}

Publication details, including instructions for authors and subscription information:

http:// www. tandfonline.com/loi/gfer20

\section{Defect-Free FLCD's with High Optical Quality Based Upon New FLC's}

V. Lapanik ${ }^{a}$, V. Bezborodov ${ }^{a}$, A. Minko ${ }^{a}$, G. Sasnouski ${ }^{a}$, W. Haase

${ }^{b} \&$ A. Lapanik ${ }^{b}$

a Institute of Applied Physics Problems, Minsk, 220064, Belarus

${ }^{b}$ Darmstadt University of Technology, Darmstadt, 64287, Germany

Version of record first published: 10 Mar 2011

To cite this article: V. Lapanik, V. Bezborodov, A. Minko, G. Sasnouski, W. Haase \& A. Lapanik (2006): Defect-Free FLCD's with High Optical Quality Based Upon New FLC's, Ferroelectrics, 344:1, $205-211$

To link to this article: http:// dx.doi.org/ 10.1080/00150190600968231

\section{PLEASE SCROLL DOWN FOR ARTICLE}

Full terms and conditions of use: http://www.tandfonline.com/page/terms-and-conditions

This article may be used for research, teaching, and private study purposes. Any substantial or systematic reproduction, redistribution, reselling, loan, sub-licensing, systematic supply, or distribution in any form to anyone is expressly forbidden.

The publisher does not give any warranty express or implied or make any representation that the contents will be complete or accurate or up to date. The accuracy of any instructions, formulae, and drug doses should be independently verified with primary sources. The publisher shall not be liable for any loss, actions, claims, proceedings, demand, or costs or damages whatsoever or howsoever caused arising directly or indirectly in connection with or arising out of the use of this material. 


\title{
Defect-Free FLCD's with High Optical Quality Based Upon New FLC's
}

\author{
V. LAPANIK,,${ }^{1, *}$ V. BEZBORODOV,${ }^{1}$ A. MINKO,${ }^{1}$ \\ G. SASNOUSKI, ${ }^{1}$ W. HAASE, ${ }^{2}$ AND A. LAPANIK ${ }^{2}$ \\ ${ }^{1}$ Institute of Applied Physics Problems, Minsk 220064, Belarus \\ ${ }^{2}$ Darmstadt University of Technology, Darmstadt 64287, Germany
}

\begin{abstract}
We have designed new FLC compounds and new FLC materials based upon them, and we have found general criteria of the preparation of FLCD's with uniform and stable orientation of FLC materials [1]. The influence of the molecular structure on the quality of orientation, on thermal and mechanical stability and on the contrast ratio was investigated by using 4 types of aligning materials in the thin and thick testing cells. The correlation between the number, type and amount of achiral and 3-, 4-ring chiral compounds in the mixture and contrast ratio of our FLCD's was found. Finally we optimized the FLC-mixtures, alignment conditions and we prepared the defect-free samples with optical contrast about 700:1.
\end{abstract}

Keywords Ferroelectric liquid crystalline materials; tilt angle; defect-free

\section{Introduction}

The surface-stabilized ferroelectric LCD's is an attractive device because of it is unique characteristics such as bistable memory capability, wide viewing angle and fast response [2]. However, it is hard to fabricate a defect-free SSFLCD's owing to the appearance of the so-called zig-zag defect that degrades memory capability and contrast ratio of the display.

The development described in this paper has solved two fundamental problems of FLCD's. The first one is shock stability and the second one is the gray scale.

Main attention of this research has focused on determining what alignment materials and surface treatments tend to produce defect-free textures. In this work, key technologies were developed in order to overcome these problems. Firstly we suggested that FLC materials may play the main role in the solution of these problems and decided that flexurally rigid rod-like chiral molecules with the definite length, the long helical pitches and a wide temperature range of the $\mathrm{SmC}^{*}$ phase are needed for this. Long helical pitches in $\mathrm{SmC}^{*}$ phases are required in order to yield a high quality of alignment FLC materials. A wide temperature range of $\mathrm{SmC}^{*}$ phase is needed for the extension of the operating temperature range of FLCD's. For this target the new FLC-mixtures base upon 3- and 4-ring chiral compounds with different positions of the lateral substitutes on the central core and with different positions of the bridge fragment were developed [1]. 


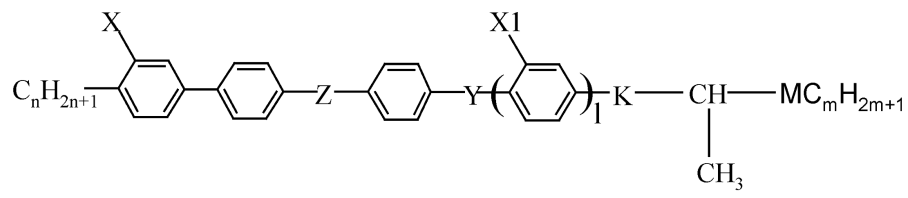

$\mathrm{n}=6-10 ; \mathrm{m}=4-6 ; \mathrm{X}, \mathrm{X} 1=\mathrm{CH} 3, \mathrm{Cl} ; \mathrm{Z}, \mathrm{Y}, \mathrm{M}=\mathrm{COO}$, single bond; $\mathrm{K}=\mathrm{O}, \mathrm{COO} ; \mathrm{l}=0-1$

Secondly we suggested that these molecules can be mixed together with a special mobile and flexible buffers like a spring. In this case the decreasing of the translation order may be observed. The influence of the molecular structure on the quality of orientation, on thermal and mechanical stability and on the contrast ratio of FLCD's was investigated using 4 types of aligning materials for thick testing cells. In fact, it has been reported before for SSFLCD fabricated using weak-surface-anchoring alignment films. For the understanding of the role of the surface morphology of the rubbed alignment layers we investigated the testing cell with the weak, medium and strong rubbing.

Finally the general criteria of manufacturing the thermal and mechanical stable FLCD's with high contrast ratio and good memory capability for the different cell-gap (from $1.5 \mu \mathrm{m}$ till $20 \mu \mathrm{m}$ ) was evaluated.

\section{Results and Discussion}

For the preparation of the FLC-mixtures we used the new flexurally rigid rod-like chiral molecules with the definite length and wide temperature range of the $\mathrm{SmC}^{*}$ phase. These molecules were mixed together with a special mobile and flexible buffers that allow similar to spring to restore instantly of the smectic layers after mechanical pressure. Firstly we optimized the type of the flexible buffer. After that the correlation between the number and amount of the 3- and 4-ring chiral compounds and special dopants was found. In this conditions the smectic layers are not broken under the pressure and only become deformed independently from the force of pressure and value of the shear (geometrical deviation) [3]. Also from XRD data we found that intensity of peak for SC 96 is higher and half-width is smaller than for LBHS-65. It means that translation order for LBHS- 65 is smaller. This confirms our suggestions that LBHS-65 is promising for the preparation shock- problem free FLCD's (see Fig. 1).

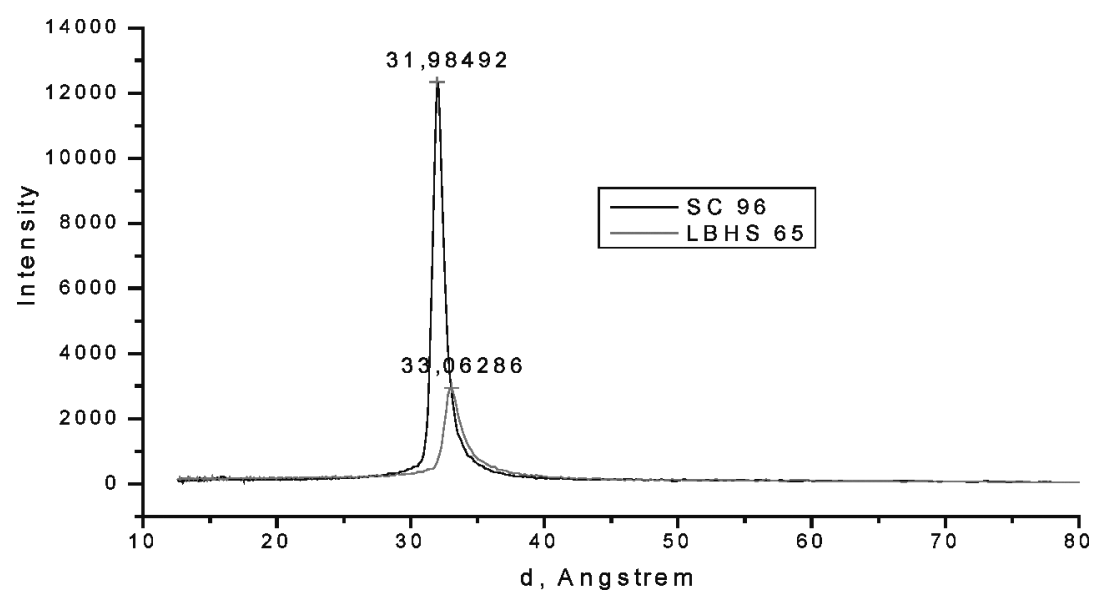

Figure 1. XRD pattern for compound SC 96 and mixture LBHS-65.(See Color Plate XXXI) 


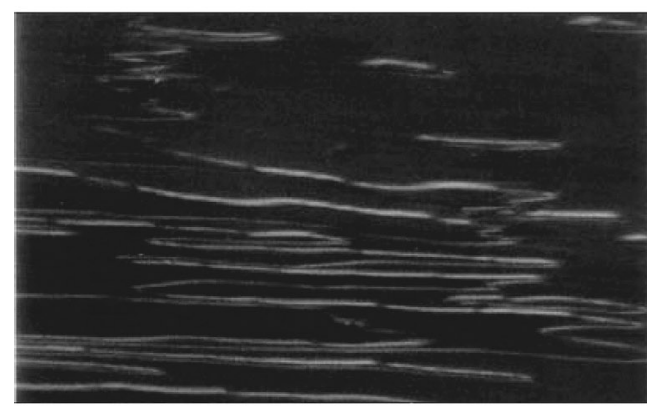

AL 1254

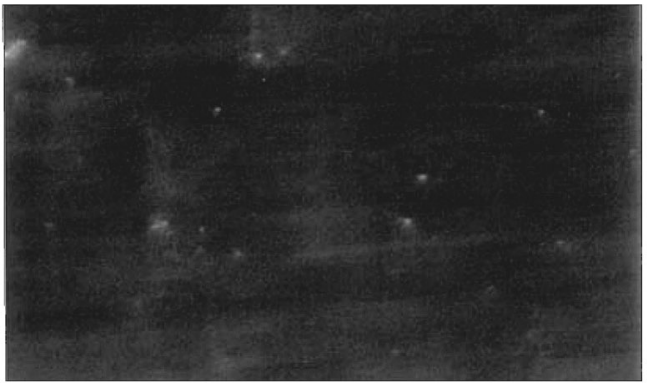

PL 3012

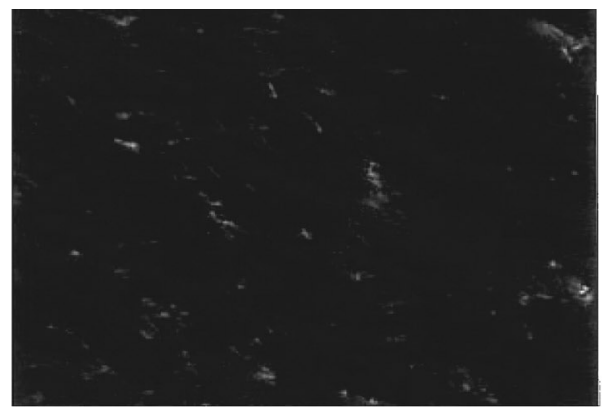

PL3001

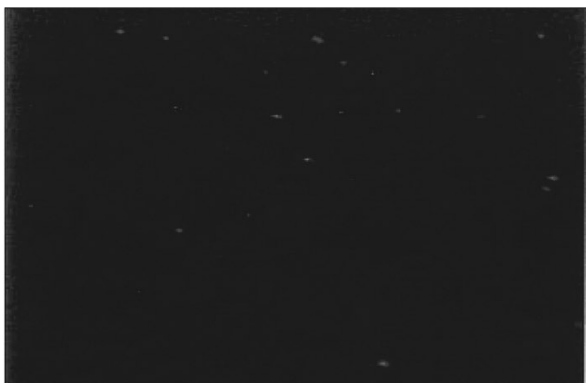

Nylon 6

Figure 2. Photographs under polarizing microscope of FLC cell with the different alignment materials. (See Color Plate XXXII)

On the first stage we investigated all our mixtures in the testing cells with cell-gap $1.5-3 \mu \mathrm{m}$ and with the weak, medium and strong rubbing using the different alignment materials (nylon 6, polyimides-Al 1254, PL 3001, PL 3012) (see Fig. 2).

The developed FLC-materials and cells with nylon 6, PL 3001 and medium rubbing possess a wide temperature range of the $\mathrm{SmC}^{*}$ phase as well as bistability, gray scale capability, low operation voltage, high optical contrast, temperature independence of the main parameters and therefore they are promising good candidates for practical application (see Fig. 3 and Table 1).

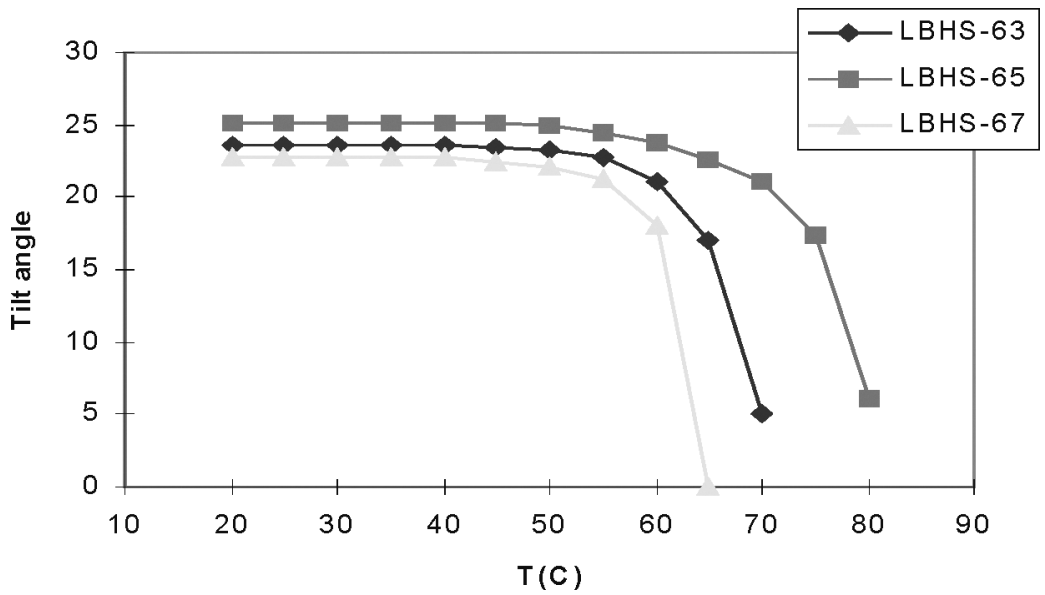

Figure 3. Temperature dependence of the tilt angle of FLC mixtures. (See Color Plate XXXIII). 
Table 1

Physical and electrooptical properties of FLC mixtures

\begin{tabular}{|c|c|c|c|c|c|c|c|}
\hline Mixtures & $\begin{array}{c}\mathrm{SmC}^{*} \\
\text { temperature } \\
\text { range }\left({ }^{\circ} \mathrm{C}\right)\end{array}$ & $\begin{array}{c}\text { Operating } \\
\text { voltage } \\
(\mathrm{V} / \mu \mathrm{m})\end{array}$ & $\begin{array}{c}\text { Spontaneous } \\
\text { polarization } \\
(\mathrm{nC} / \mathrm{cm} 2)\end{array}$ & $\begin{array}{l}\text { Contrast } \\
\text { ratio }\end{array}$ & $\mathrm{t}_{\mathrm{on}}(\mathrm{ms})$ & $\mathrm{t}_{\mathrm{off}}(\mathrm{ms})$ & $\begin{array}{c}\text { Tilt } \\
\text { angle }\end{array}$ \\
\hline SC 96 & $20<-+117.2$ & 10 & 112 & $11: 1$ & 2.0 & 2.1 & 33.2 \\
\hline SC 106 & $20<-+98.6$ & 10 & 107 & $10: 1$ & 1.91 & 1.95 & 28.7 \\
\hline LBHS-55 & $20<-+74.7$ & 10 & 21 & $65: 1$ & 0.62 & 0.63 & 23.9 \\
\hline LBHS-56 & $20<-+68.3$ & 10 & 21 & $52: 1$ & 0.6 & 0.61 & 23.7 \\
\hline LBHS-59 & $20<-+99.3$ & 10 & 31 & $44: 1$ & 0.78 & 0.83 & 30.6 \\
\hline LBHS-63 & $20<-+73.4$ & 10 & 23 & $500: 1$ & 0.52 & 0.53 & 23.8 \\
\hline $\begin{array}{l}\text { LBHS-63 } \\
\qquad \text { (AL-1254) }\end{array}$ & $20<-+73.4$ & 10 & 21 & $134: 1$ & 0.48 & 0.49 & 23.4 \\
\hline $\begin{array}{l}\text { LBHS-63 } \\
\text { (PL-3001) }\end{array}$ & $20<-+73.4$ & 10 & 21 & $77: 1$ & 0.43 & 0.44 & 23.2 \\
\hline LBHS-65 & $20<-+74.5$ & 10 & 21 & $140: 1$ & 0.34 & 0.35 & 25.3 \\
\hline $\begin{array}{l}\text { LBHS-65 } \\
\qquad \text { (AL-1254) }\end{array}$ & $20<-+74.5$ & 10 & 23 & $125: 1$ & 0.32 & 0.33 & 24.9 \\
\hline $\begin{array}{l}\text { LBHS-65 } \\
\qquad \text { (PL-3001) }\end{array}$ & $20<-+74.5$ & 10 & 24 & $74: 1$ & 0.31 & 0.31 & 24.7 \\
\hline LBHS-67 & $20<-+64.5$ & 10 & 12 & 690:1 & 0.48 & 0.49 & 22.8 \\
\hline LBHS-69 & $20<-+88.8$ & 10 & 25 & 210:1 & 0.35 & 0.36 & 25.4 \\
\hline LBHS-70 & $20<-+84.2$ & 10 & 23 & $44: 1$ & 0.62 & 0.63 & 23.2 \\
\hline LBHS-71 & $20<-+75.1$ & 10 & 27 & 170:1 & 0.28 & 0.28 & 25.9 \\
\hline LBHS-72 & $20<-+60.2$ & 10 & 25 & $78: 1$ & 0.62 & 0.63 & 26.5 \\
\hline LBHS-73 & $20<-+69.3$ & 10 & 89 & $82: 1$ & 0.32 & 0.31 & 29.7 \\
\hline LBHS-77 & $20<-+87.9$ & 10 & 19 & $44: 1$ & 0.52 & 0.53 & 27.2 \\
\hline LBHS-81 & $20<-+91.5$ & 10 & 149 & $30: 1$ & 0.21 & 0.21 & 18.3 \\
\hline LBHS-84 & $20<-+84.2$ & 10 & 23 & $44: 1$ & 0.62 & 0.63 & 23.2 \\
\hline
\end{tabular}

The maximum contrast ratio 700:1 was achieved for the best testing cell (see Fig. 4). Our first cells were prepared 10 months ago. During this period we checked them on the thermal and mechanical stability. One day in the week we become deformed under pressure our cells when shear (geometrical deviation) was more than $60 \%$ (for example: when we pushed on the cells the thickness of them was decreased from $3.5 \mu \mathrm{m}$ till $1.5 \mu \mathrm{m}$ ). We did

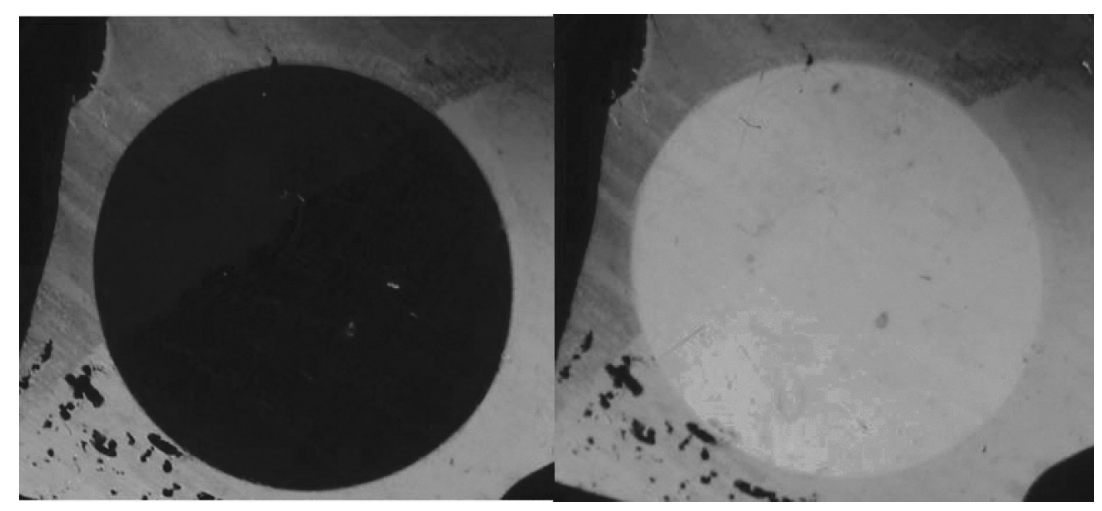

Figure 4. The example of defect-free cells with high contrast ratio (LBHS-67, $d=1.7 \mu \mathrm{m}$ ). (See Color Plate XXXIV) 


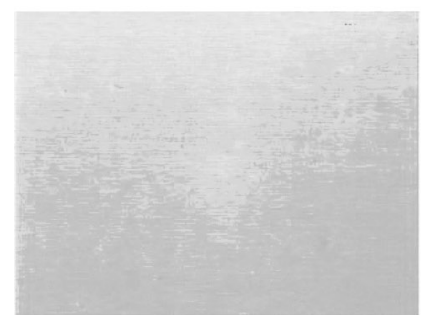

turn on

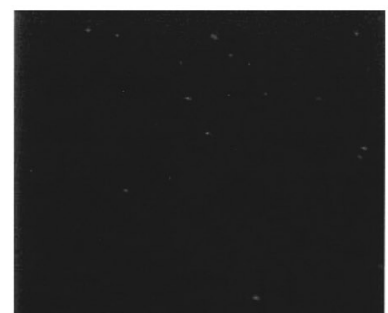

before deformation

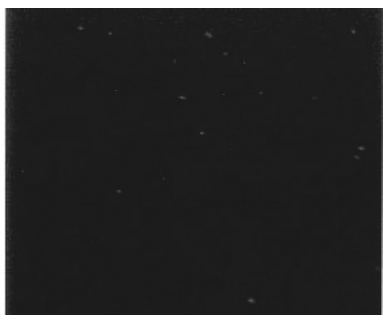

after mechanical pressure

Figure 5. Photographs under polarizing microscope of FLC cell before and after strong pressure during long time [when shear (geometrical deviation) more than 60\%]. (See Color Plate XXXV)

not find any changes after that, all these cells are defect-free and are characterized the same alignment quality. The thermal stability of the samples is very good also (see Fig. 5).

We did not investigate our cell when shear was more than $60 \%$, because cells were broken under such pressure.

Then we decided to check what is maximum thickness when the cells do not have the shock problems. Our investigations have shown that the structure of the molecules very strongly influences the possibility of good orientation of FLC materials in thick cells also. We found that a special mobile and flexible buffers very strong influence on the maximum oriented cell gap and value of contrast ratio (see Table 2, Figs. 6 and 7).

This is a threshold effect (thickness of the cell when the smectic layers are not oriented). Finally we prepared thermal and mechanical stable samples with a cell-gap of about $21 \mu \mathrm{m}$ (see Fig. 8).

The first thick cells were prepared 7 months ago. During this period we checked them on the thermal and mechanical stability. One day in the week we pressured our cells when shear (geometrical deviation) was 50-60\% (for example: when we pushed on the cells the thickness of them was decreased from $16.5 \mu \mathrm{m}$ till $8.0 \mu \mathrm{m}$ ). We did not find any changes for $50 \%$ shear and big changes for $60 \%$ shear after that. For first case all these cells are defectfree and are characterized the same alignment quality and for the second case contrast ratio decreased only a $10 \%$.

\section{Experimental}

The structures of the prepared compounds were confirmed by ${ }^{1} \mathrm{H}-\mathrm{NMR}$ and mass spectroscopy. Phase transition temperatures were measured using a Linkam heating stage having a polarizing PZO microscope and also using a Setaram DSC 92.

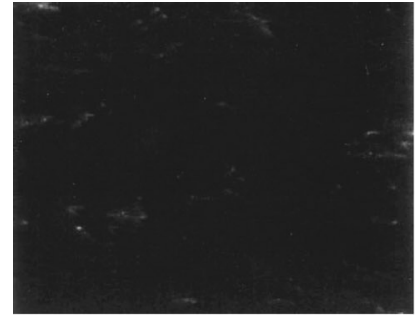

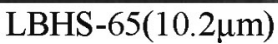

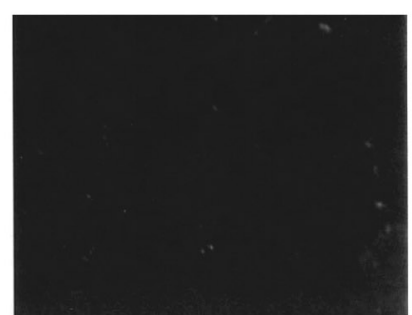

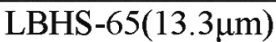

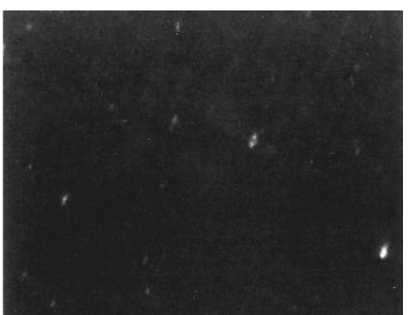

LBHS-65(16.5 $\mu \mathrm{m})$

Figure 6. Photographs under polarizing microscope of FLC cells with the different thickness. (See Color Plate XXXVI) 
Table 2

Physical and electrooptical parameters of the FLC mixtures

\begin{tabular}{|c|c|c|c|c|c|c|c|}
\hline Mixtures & $\begin{array}{l}\mathrm{SmC}^{*} \\
\text { temperature } \\
\text { range }\left({ }^{\circ} \mathrm{C}\right)\end{array}$ & $\begin{array}{c}\text { Operating } \\
\text { voltage } \\
(\mathrm{V} / \mu \mathrm{m})\end{array}$ & $\begin{array}{c}\text { Spontaneous } \\
\text { polarization } \\
\left(\mathrm{nC} / \mathrm{cm}^{2}\right)\end{array}$ & $\begin{array}{l}\text { Contrast } \\
\text { ratio }\end{array}$ & $\mathrm{t}_{\mathrm{on}}(\mathrm{ms})$ & Tilt angle & $\begin{array}{l}\text { Cell gap } \\
(\mu \mathrm{m})\end{array}$ \\
\hline \multirow[t]{4}{*}{ LBHS-63 } & \multirow[t]{4}{*}{$20<-+73.4$} & \multirow[t]{4}{*}{3} & 22 & $92: 1$ & 0.53 & 23.5 & 9.2 \\
\hline & & & 22 & 55.1 & 0.51 & 23.6 & 12.2 \\
\hline & & & 21 & $31: 1$ & 0.52 & 23.8 & 15.9 \\
\hline & & & 21 & $20: 1$ & 0.52 & 23.9 & 20.4 \\
\hline $\begin{array}{l}\text { LBHS-63 } \\
\text { (AL-1254) }\end{array}$ & $20<-+73.4$ & 3 & 21 & $19: 1$ & 0.48 & 23.4 & 16.1 \\
\hline $\begin{array}{l}\text { LBHS-63 } \\
\quad(\text { PL-3001) }\end{array}$ & $20<-+73.4$ & 3 & 21 & $15: 1$ & 0.43 & 23.4 & 16.3 \\
\hline \multirow[t]{4}{*}{ LBHS-65 } & \multirow[t]{4}{*}{$20<-+74.5$} & \multirow[t]{4}{*}{3} & 25 & $77: 1$ & 0.35 & 25.3 & 10.2 \\
\hline & & & 25 & $41: 1$ & 0.35 & 25.3 & 13.3 \\
\hline & & & 24 & $27: 1$ & 0.36 & 25.4 & 16.5 \\
\hline & & & 24 & $15: 1$ & 0.36 & 25.4 & 20.8 \\
\hline $\begin{array}{l}\text { LBHS-65 } \\
\text { (AL-1254) }\end{array}$ & $20<-+74.5$ & 3 & 25 & $17: 1$ & 0.32 & 25.2 & 16.2 \\
\hline $\begin{array}{l}\text { LBHS-65 } \\
\quad(\text { PL-3001) }\end{array}$ & $20<-+74.5$ & 3 & 25 & $12: 1$ & 0.31 & 25.1 & 16.2 \\
\hline \multirow[t]{4}{*}{ LBHS-65 } & \multirow[t]{4}{*}{$20<-+75.1$} & \multirow[t]{4}{*}{3} & 27 & $85: 1$ & 0.32 & 25.8 & 9.9 \\
\hline & & & 27 & $47: 1$ & 0.32 & 25.9 & 12.7 \\
\hline & & & 26 & $29: 1$ & 0.33 & 25.9 & 16.2 \\
\hline & & & 26 & $17: 1$ & 0.33 & 25.9 & 19.9 \\
\hline $\begin{array}{l}\text { LBHS-71 } \\
\qquad(A L-1254)\end{array}$ & $20<-+75.1$ & 10 & 27 & $19: 1$ & 0.31 & 25.6 & 15.9 \\
\hline $\begin{array}{l}\text { LBHS-71 } \\
\quad(\text { PL-3001) }\end{array}$ & $20<-+75.1$ & 10 & 27 & $15: 1$ & 0.30 & 25.5 & 16.2 \\
\hline
\end{tabular}

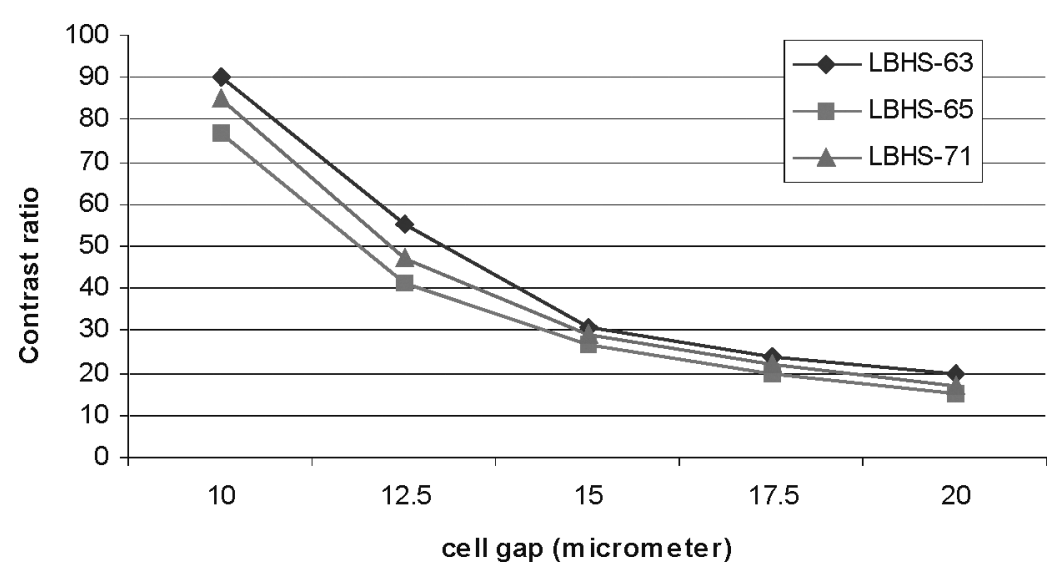

Figure 7. Contrast ratio dependence of the thickness of the cell. (See Color Plate XXXVII) 

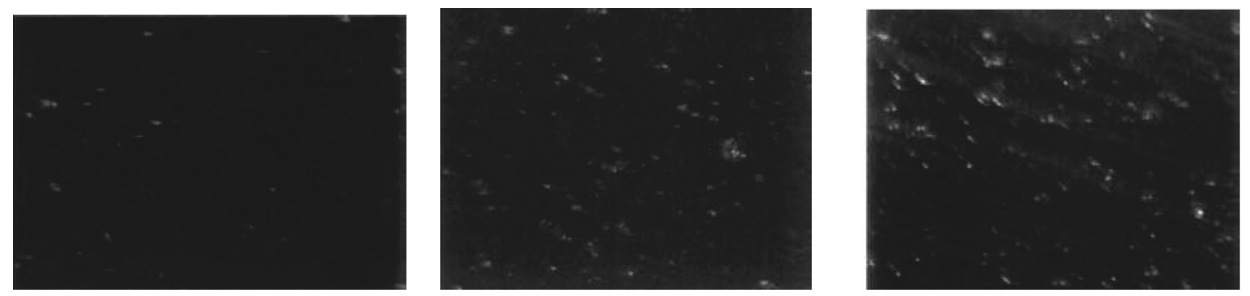

before deformation after mechanical pressure(50\%) after mechanical pressure( $60 \%)$

Figure 8. Photographs under polarizing microscope of FLC cell $(\mathrm{d}=20.8 \mu \mathrm{m})$ before and after moderate or strong pressure during long period [when shear (geometrical deviation) less than $50 \%$ and more than $60 \%$ ]. (See Color Plate XXXVIII)

The solution of the alignment materials [nylon 6, polyimides (Al 1254, PL-3001, PL3012) 80-120 nm] was spun onto the indium-tin-oxid(ITO) substrate(with the receptivity about $20-30 \Omega / \mathrm{cm}^{2}$ ) at $3000 \mathrm{rpm}$ rate and them baked at $180^{\circ} \mathrm{C}$ for 1 hour for the imidization to get the polyimide film. Aligning layers were unidirectional rubbed under a velvet-covered cylinder. The thickness of the cells was about 1.5-21 $\mu \mathrm{m}$ and measured in each case interferometrically. The microscope textures of the SSFLC cells were observed using a polarising microscope. The EO properties of the SSFLC cells were measured between the crossed polarizers using a He-Ne laser. The light transmittance was detected by a photomultiplier and recorded in a digital oscilloscope. The contrast ratio was measured under the application of $\mathrm{a}+-10 \mathrm{~V} / \mu \mathrm{m}, 10 \mathrm{~Hz}$ rectangular voltage. The rice and decay times are defined as the transmittance changes from $10 \%-90 \%$ and vice versa. The bistability (or the memory capability) was measured using a $1 \mathrm{~ms}$ bipolar pulse with a period of $20 \mathrm{~ms}$. During electro-optic measurements the temperature of the cells was controlled with the accuracy $0.3^{\circ} \mathrm{C}$.

XRD measurements were made on STOE Stadi 4 plant with standard 1, 1.5, $2 \mathrm{~mm}$ capillaries (from Hilgenberg)

\section{Conclusion}

- Correlation between the chemical structures of molecules and shock-problem free FLCD's was found

- Correlation between the amount of the flexurally rigid rod-like chiral molecules with the definite length, mobile and flexible buffers (spring) and contrast ratio was found

- These results show that the defect-free FLCD's when shear (geometrical deviation) more than $60 \%$ with small thickness $(<5 \mu \mathrm{m})$ and less than $50 \%$ with large thickness $(>15 \mu \mathrm{m})$ are real and can be practically realized.

- Correlation between the amount and type of mobile and flexible buffers (spring) in the mixture and maximum thickness for defect-free cells was found

- Correlation between the chemical structures of molecules and contrast ratio for thick cells was found

\section{References}

1. V. Lapanik, V. Bezborodov, A. Minko, et al. Mol. Cryst. Liq. Cryst., 439, 1945 (2005).

2. Lu. Ruido, Wu. Shin-Tson, and Xu. Keshu, Jpn. J. Appl. Phys., vol.42, pp.1628-1632 (2003).

3. N. Wakita, T. Uemura, H. Ohnishi, et al. Ferroelectrics, 149, 229-238 (1993). 